\title{
PENDISTRIBUSIAN PUPUK BERSUBSIDI YANG BERIMPLIKASI TINDAK PIDANA EKONOMI
}

Oleh :

\author{
Danu Bagus Pratama
}

Email : danubagus@gmail.com

Universitas Airlangga

\begin{abstract}
Abstrak
Pupuk mempunyai peran yang strategis serta penting untuk meningkatkan produksi maupun produktivitas pertanian. Pada dasarnya tindak pidana ekonomi dalam pendistribusian pupuk ini banyak dilakukan oleh para oknum-oknum terkait karena adanya celah hukum pada setiap regulasi yang mengatur tentang pengadaan, pengawasan maupun pendistribusian pupuk. Tujuan yang ingin diperoleh penulis dengan penelitian ini ialah untuk menganalisis karakteristik tindak pidana yang dilarang dan diancam pidana terkait dalam pendistribusian pupuk bersubsidi dan untuk menganalisis pertanggung-jawaban pidana pelaku pendistribusian pupuk bersubsidi, yang berimplikasi tindak pidana. Pendekatan yang digunakan dalam penulisan ini ialah pendekatan perundang-undangan, pendekatan konseptual maupun diaplikasikan dalam studi kasus
\end{abstract}

Kata Kunci : tindak pidana ekonomi, pupuk, subsidi, pertanian,

\begin{abstract}
Fertilizer has a strategic and important role to increase agricultural production and productivity. Therefore, the government, with a variety of policies covering technical aspects, supply and distribution despite subsidized prices, continues to encourage the use of fertilizers efficiently. Basically, the economic crime in distributing fertilizer is mostly carried out by related individuals because of the legal loopholes in any regulations governing the procurement, supervision and distribution of fertilizers. The aim of the writer with this research is to analyze the characteristics of criminal acts that are prohibited and punishable by crimes related to the distribution of subsidized fertilizers and to analyze the criminal responsibility of the perpetrators of distributing subsidized fertilizers, which have implications for criminal acts. The approach used in this paper is the statutory approach, conceptual approach or applied in case studies
\end{abstract}

Keywords : economic crime, fertilizers, subsidies, agriculture 


\section{PENDAHULUAN}

\subsection{Latar Belakang}

Indonesia terkenal dengan kesuburan tanahnya, namun karena banyaknya sektor pembangunan daerah maka diperlukan beberapa bahan tambahan untuk meningkatkan kesuburan tanah pertanian di Indonesia, salah satunya adalah penggunaan Pupuk. Terdapat banyak perusahaan industri pupuk pertanian, selain pabrik pupuk besar milik BUMN tersebut, yang menghasilkan berbagai macam jenis pupuk padat/cair organik (alam, kompos dan kandang) ataupun non organik (kimia) contohnya tsp, bokasi, dolomit, urea, phosphate, npk, za, dan lain sebagainya. Sebagian besar lokasi pabrik itu tersebar di seluruh wilayah provinsi di Indonesia

Khusus pabrik pupuk besar milik BUMN sebagai pengemban tugas ketahanan pangan nasional, PT Pupuk Indonesia (Persero) begitu juga tujuh anak perusahaannya tersebut menjalankan 13 pabrik amoniak serta 14 pabrik urea di beberapa wilayah yang tersebar di Pulau Kalimantan, Jawa serta Sumatera. PT Pupuk Indonesia yakni BUMN yang sebelumnya diketahui melalui nama PT Pupuk Sriwidjaja (Persero) ataupun PUSRI selaku produsen pertama pupuk urea di Indonesia. Kini, PT Pupuk Indonesia yakni produsen pupuk paling besar di Asia Tenggara yang mempunyai total aset sejumlah Rp. 39,31 triliun di tahun 2011 dengan total kapasitas produksi pupuk sejumlah 19,14 juta ton/tahun. PT Pupuk Indonesia sebagai Strategic Investment Holdin yaitu selaku perusahaan yang terintegrasi untuk melaksanakan beraneka macam usaha yang menunjang aktivitas utama, sebagaimana perkebunan, pertanian, pertambangan, pengangkutan maupun optimalisasi pemanfaatan sumber daya. Di masa mendatang PT Pupuk Indonesia hendak membentuk beberapa perusahaan baru guna menunjang aktivitas utama itu.

Pupuk merupakan material yang ditambahkan ke media tanam ataupun tanaman guna mencukupi kebutuhan hara yang dibutuhkan tanaman kemudian dapat berproduksi secara baik. Material pupuk bisa berbentuk material non organik ataupun organik. $^{1}$

Beraneka ragam upaya pemerintah untuk memberikan fasilitas serta meningkatkan kualitas pada bidang pertanian, khususnya pada sektor ketahanan pangan nasional. Lebih lanjut, pemerintah juga sudah menerbitkan beraneka ragam peraturan mengenai guna meningkatkan bidang pertanian, beberapa diantaranya yakni peraturan perihal pupuk bersubsidi.

Kebijakan pupuk bersubsidi telah dikeluarkan Pemerintah yang telah berjalan sejak tahun 2003 sampai dengan sekarang.

${ }^{1}$ www.psp.pertanian.go.id/index.php/page/publikasi/ 300, diunduh 16/01/2019, 10.58 WIB. 
Peraturan Menteri Perdagangan No 15/MDAG/PER/4/2013 mengenai Pengadaan dan Penyaluran Pupuk Bersubsidi guna Sektor Pertanian merupakan pengaturan tentang penyaluran dan pengadaan serta pengertian pupuk bersubsidi.

Definisi pupuk bersubsidi diuraikan pada Pasal 1 angka 1 Permendagri No 15/M-DAG/PER/4/2013 mengenai Pengadaan dan Penyaluran Pupuk Bersubsidi guna Sektor Pertanian, yakni seperti di bawah ini:

"Pupuk Bersubsidi ialah barang dalam pengawasan yang pengadaan serta penyalurannya memperoleh subsidi dari pemerintah untuk kebutuhan kelompok Tani dan/atau Petani di sektor pertanian mencakup atas pupuk Urea, Pupuk SP 36, Pupuk ZA, Pupuk NPK serta jenis pupuk bersubsidi yang lain yang ditetapkan oleh menteri yang melaksanakan urusan Pemerintah pada bidang pertanian."

Perihal tersebut dilaksanakan oleh Pemerintah supaya petani memperoleh pupuk yang memiliki harga yang ekonomis. Peraturan Menteri Pertanian No 60/ Permentan/SR.130/12/2015 mengenai Penetapan Kebutuhan Harga Eceran Tertinggi (HET) Pupuk Bersubsidi juga telah dikeluarkan pemerintah guna Sektor Pertanian. Pemerintah berharap melalui terdapatnya peraturan itu, pendistribusian serta pemakaian pupuk bersubsidi tepat sasaran, maka sebab itu sangat diharapkan komitmen serta dukungan pengawalan maupun pengawasan dari beragam pihak khususnya Pemerintah Daerah.

Dalam beberapa tahun terakhir ini banyak sekali pelanggaran yang terkait pendistribusian pupuk bersubsidi, antara lain pelanggaran merk dagang, perbedaan label dengan isi dan jenis pupuk, penimbunan pupuk oleh tengkulak dan masih banyak pelanggaran-pelanggaran lain yang berimplikasi tindak pidana ekonomi. Pupuk bersubsidi yang telah diatur proses distribusinya serta diberikan pengawasan sampai pada kios resmi mitra Kementan. Kasus penyelewengan didapatkan pula di Riau, tidak sampainya pupuk bersubsidi kepada kelompok tani yang semestinya mempunyai hak mendapatkan gara-gara dilakukan penyelewengan dari pengelola kios. Pengelola kios sudah memperoleh pupuk subsudi berdasarkan atas total yang tercatat dalam RDKK dari Desa Serumpun Jaya, Kecamatan Pasir Penyu, Kabupaten Inhu, Riau. Pemilik Kios Tani Rakyat, menggunakan identitas orang lain yakni pimpinan Kios Tani Rakyat yang memiliki nama Supriono, guna menjual pupuk bersubsidi pada desa lainnya melalui harga yang lebih tinggi. ${ }^{2}$

\footnotetext{
${ }^{2}$ https://www.jitunews.com/read/56356/parahbegini-modus-penyelewengan-pupuk-ureasubsidi-di-riau, diakses 15 januari 2019, 11.20 WIB
} 
Modus operandi lain yang berkaitan dengan pendistribusian pupuk, salah satunya sebagaimana dilakukan oleh $\mathrm{H}$. Arif Nur Saifullah selaku pengecer atau kios resmi pupuk di Kecamatan Sukomoro Kabupaten Nganjuk yang telah memperjualbelikan pupuk bersubsidi jenis pupuk organik Petroganik yang diproduksi oleh PT. Pupuk Indonesia (Persero) Group di luar bagian maupun di luar daerah tanggung jawabnya seperti yang dimaksudkan pada Pasal 30 (2) Jo Pasal 21 (1) Permendag RI No. 15/M-DAG/PER/4/2013 Jo Pasal 6 (1) b UU Drt. No. 7 Tahun 1955, yang tertuang pada Putusan Pengadilan Negeri Nganjuk No 307/Pid.Sus/2016/PN.Njk.

Pada dasarnya tindak pidana ekonomi dalam pendistribusian pupuk ini banyak dilakukan oleh para oknum-oknum terkait karena adanya celah hukum pada setiap regulasi yang mengatur tentang pengadaan, pengawasan maupun pendistribusian pupuk. Untuk menghindari adanya pelanggaran-pelanggaran dengan modus baru demi meraup keuntungan yang besar maka sekiranya Hukum Pidana Ekonomi di Indonesia harus terus diperbarui mengikuti perkembangan zaman.

Menarik untuk dianalisis dalam penelitian ini adalah kasus PT. Mega Berlian Indonesia yang bertempat pada wilayah hukum Pengadilan Lampung Utara di Kotabumi. PT. Mega Berlian Indonesia sudah dibubarkan/dilikuidasi oleh Kejaksaan
Negeri Lampung Utara dimana I Gede Berlian MS selaku Direktur Utama perseroan itu sudah terbukti melakukan kesalahan dengan melaksanakan tindak pidana "Secara sengaja melakukan pengedaran pupuk yang tidak berdasarkan atas label" berdasarkan Putusan Pengadilan Negeri Kotabumi No 86/Pid.Sus/2015/PN.Kbu tanggal 22 Oktober 2015, bahwa PT. Mega Berlian Indonesia tersebut ialah sebuah perseroan bergerak pada bidang Produksi Pupuk, bahwa dengan adanya putusan pidana tersebut Kepala Kejaksaan Negeri Lampung Utara selaku pemohon sebagai Jaksa Pengacara Negara menganggap bidang usaha yang dilaksanakan PT. Mega Berlian Indonesia sudah melakukan pelanggaran terhadap aturan perundang-undangan/ melanggar kepentingan umum, sehingga sesuai ketentuan dalam Pasal 146 UU No 40 Tahun 2007 mengenai Perseroan Terbatas menjelaskan jika "Pengadilan Negeri bisa membubarkan perseroan atas permohonan kejaksaan berlandaskan alasan perseroan melakukan pelanggaran terhadap kepentingan umum ataupun perseroan melaksanakan tindakan melanggar aturan perundang-undangan". Berpedoman pada Pasal 146 UU No 40 Tahun 2007 mengenai Perseroan Terbatas, pemohon mengajukan pembubaran terhadap perseroan PT. Mega Berlian Indonesia ke Pengadilan Negeri Kotabumi, Lampung Utara dan sekaligus 
menunjuk Likuidator Balai Harta Peninggalan Jakarta.

Perihal ini BHP menindaklanjuti Penetapan Pengadilan Negeri Kotabumi, Lampung Utara No 15/Pdt.P/2015/PN.Kbu tanggal 18 Februari 2016 pada amar penetapan itu BHP Jakarta ditetapkan selaku Likuidator serta menetapkan Jaksa Pengacara Negara selaku Anggota Tim Likuidator, Kedatangan Tim Likuidator tersebut memiliki tujuan guna mengurus serta menyelesaikan segala sesuatu terkait boedel/harta kekayaan PT. Mega Berlian Indonesia atas tanggung jawabnya terhadap para kreditornya.

\subsection{Rumusan Masalah}

Berdasarkan pemaparan dalam latar belakang tersebut bisa dilakukan rumusan permasalahan diantaranya yakni seperti berikut: Apa karakteristik tindak pidana ekonomi dalam kaitannya dengan pendistribusian pupuk bersubsidi? Bagaimanakah pertanggungjawaban pidana bagi pelaku distribusian pupuk bersubsidi yang berimplikasi tindak pidana?

Tujuan yang ingin diperoleh penulis dengan penelitian ini ialah seperti berikut : Untuk menganalisis karakteristik tindak pidana yang dilarang dan diancam pidana terkait dalam pendistribusian pupuk bersubsidi. Untuk menganalisis pertanggungjawaban pidana pelaku pendistribusian pupuk bersubsidi, yang berimplikasi tindak pidana.

\section{METODE PENELITIAN}

Tipe penelitian yang akan dilakukan ialah penelitian hukum normatif, yakni sebuah penelitian hukum yang melakukan analisis terhadap peraturan-peraturan hukum yang berhubungan terhadap suatu inti permasalahan tertentu. ${ }^{3}$ Dalam pembahasan permasalahan yang dipakai pada penulisan ini, penulis menggunakakan bentuk pendekatan perundang-undangan, pendekatan konseptual maupun diaplikasikan dalam studi kasus.

Pendekatan perundangan-undangan (statute approach) ialah pendekatan dengan memakai legislasi serta regulasi. Pendekatan konsep (conceptual approach) merupakan pendekatan yang dilaksanakan melalui cara memberikan jawaban terhadap permasalahan-permasalahan yang ada dengan melandaskan konsep, sejumlah pandangan serta doktrin-dokrin yang terdapat pada ilmu hukum. Dan pendekatan kasus (case study) dilakukan dengan mempelajari resume perkara, surat dakwaan, dan surat tuntutan yang selanjutnya akan dipakai selaku pengungkapan fakta materiil yang berlangsung.

3 Peter Mahmud Marzuki, Penelitian Hukum, Kencana, Jakarta, 2010, hlm. 15 
PEMBAHASAN

\subsection{Karakteristik Tindak Pidana}

\section{Ekonomi Dalam Pendistribusian}

\section{Pupuk Bersubsidi}

Suatu tindakan yang dilakukan secara sengaja (omissi) disebut kejahatan. Dalam hal ini seseorang dihukum harus ada suatu tindakan atau kealpaan atau bertindak, bukan hanya karena pikirannya. Kejahatan juga dapat berupa kegagalan untuk bertindak, apa ada sebuah kewajiban hukum bertindak pada kasus tertantu. Selain itu juga harus terdapat niat jahat (criminal intens, mens rea). Kejahatan bisa berlangsung dimana saja serta pada bidang apa saja tidak terkecuali dalam lapangan hukum pidana ekonomi seperti penyalahgunaan pupuk bersubsidi yang pengaturannya terdapat pada Permendag RI No 15/MDag/Per/4/2013 mengenai Pengadaan Dan Penyaluran Pupuk Bersubsidi Untuk Sektor Pertanian junto UU Darurat No 7 Tahun 1955 mengenai Pengusutan, Penuntutan dan Peradilan Tindak Pidana Ekonomi.

Pupuk yang pengadaan serta penyalurannya ditataniagakan telah ditentukan di timgkat pengecer resmi ataupun kelompok tani dengan HET yang ialah pengertian dari pupuk bersubsidi. Untuk memonitor pengadaan dan pemyaluran pupuk yang diperoleh dari subsidi, dirasa memerlukan penetapam pupuk bersubsidi termasuk dalam barang dalam pengawasan.
Dilaksanakannya Pasal 3 Perpres No 77 Tahun 2005 terkait Penetapan Pupuk Bersubsidi selaku Barang Dalam Pengawasan guna terjaminnya demi terwujudnya pengadaan serta penyaluran pupuk bersubsidi pada petani, diterbitkannya Permendag RI No. 15/MDag/Per/4/2013 mengenai Pengadaan Dan Penyaluran Pupuk Bersubsidi Untuk Sektor Pertanian yang menjelaskan tanggung jawab Produsen, Distributor, Pengecer serta Pengawasan dalam penyelenggaraan di lapangan dari pemerintah.

Diperlukannya pengawasan peredaran pupuk bersubsidi guna memberi bantuan terhadap petani sebagai usaha untuk meningkatkan produksi tanaman pangan juga usaha untuk peningkatan produksi tanaman perkebunan. APBN yang telah disetujui digunakan sebagai pengadaan pupuk bersubsidi yang sebelumnya telah dilakukan persetujuan terlebih dahukulu. Pengadaan pupuk dilakukan berdasar atas kebutuhan setiap provinsi yang di hitung serta ditetapkan melauli Peraturan Menteri Pertanian tiap tahunnya. Peraturan Menteri itu memuat terkait kebutuhan serta HET pupuk bersubsidi untuk bidang pertanian pada tahun anggaran berlangsung. Sementara itu, SK Bupati/Wali Kota menetapkan jumlah dan jenis pupuk bersubsidi per kabupaten. Sedangkan ditetapkannya pupuk bersubsidi selaku barang dalam pengawasan yang di atur lewat Perpres No 77 Tahun 
2005 dengan harapan program pupuk bersubsidi sesuai dengan sasaran. Hal ini berarti, perputaran pupk bersubsidi terdapat dalam pengawasan beberapa pihak terkait.

Pengadaan dam penyaluran pupuk, umumnya dilakukan pengaturan pada Permendag RI No 15/MDag/Per/4/2013 mengenai Pengadaan Dan Penyaluran Pupuk Bersubsidi Untuk Sektor Pertanian. Terdapat alasan yang menyebabkan penyalahgunaan pupuk bersubsidi semakin marak, pelaku yang aktif melakukan penyalahgunaan pupuk bersubsidi terdapat dalam faktor internal dari pelaku itu sendiri. Kurangnya kesadaran hukum yang menimbulkan disparitas besarnya harga dan dilakukannya tindakan yang menyimpang menjadi sumber dari faktor internal tersebut sehingga terdorong untuk melakukan penyimpangan dalam bentu menyalahgunakan pupuk bersubsidi secara illegal dengan menggunakan modus-modus tertentu. Atas dasar sumber dari Permentan No 59/PERMENTAN/SR.310/12/2016 mengenai Perubahan Atas Peraturan Menteri Pertanian No 60/PERMENTAN/SR.310/ $12 / 2015$.

Dengan rincian harga pupuk bersubsidi tahun 2018-2019 : Rp 1800/kg untuk Pupuk Urea, Rp 2000/kg untuk Pupuk SP36, Rp 1400/kg untuk Pupuk ZA, Rp 2300/kg untuk Pupuk NPK, dan Rp 400/kg untuk Pupuk Organik. Hal ini yang akhirnya membuat pelaku penyalah-gunaan pupuk bersubsidi menganggap hal ini adalah hal yang wajar untk menyalahgunakan pupuk bersubsidi.

Faktor eksternal adalah faktor-faktor diluar dari pelaku penyalahgunaan pupuk bersubsidi, antara lain :

a. Rendahnya pengawasan

Hal ini bersumber dari minimnya koordinasi lintas sektor unsur aparatur pemerintah terkait penyaluran pupuk bersubsidi. Dengan rendahnya pengawasan tersebut, pelaku memanfaatkan kondisi ini guna mengembangkan modus penyalahgunaan pupuk bersubsidi.

b. Disparitas harga

Harga pupuk non subsidi cenderung meningkat tajam dengan kisaran harga lebih dari dua kali lipat dari harga pupuk bersubsidi. Kondisi ini menimbulkan disparitas harga yang cukup besar dan mendorong untuk melakukan tindakan menyimpang dalam bentuk penyalahgunaan pupuk bersubsidi secara illegal dengan berbagai modus tertentu. Sehingga pelaku penyalahgunaan pupuk bersubsidi beranggapan bahwa merupakan hal yang wajar melakukan penyalahgunaan pupuk bersubsidi.

Tersedianya pupuk di lapangan dirasa dapat membantu untuk melaksanakan usaha taninya. Lebih lanjut, lemahnya kemampuan daya beli petani juga harus di- 
perhatikan dan juga kesan dari kebutuhan pupuk yang selalu kurang di lapangan. Berdasarkan hal tersebut, partisipasi dan kerjasama dari berbagai pihak sangat diperlukan agar pupuk bersubsidi itu bisa disalurkan secara baik sampai kepada petani diperlukan juga kontribusi secara aktif. Adapun Disperindag mempunyai tanggung jawab untuk menunjuk produsen sebagai penyedia pupuk, distributor yang berasal dari pihak swasta dan juga masyarakat dalam hal ini adalah para petani sebagai pengecer.

Dalam hal kurangnya produksi pupuk bersubsidi bukanlah penyebab utama dari langkanya pupuk bersubsidi kan tetapi lebih condong terjadi akibat banyaknya penyimpangan dalam sistem distribusi. Tidak jauh berbeda terhadap permasalahanpermasahalan lain seperti dalam hal penyimpanan serta pemasaran pupuk bersubsidi yang biasanya bermula dalam sistem distribusi yang belum terkoordinasi secara baik dan efektif.

Sejumlah penyimpangan pada pendistribusian pupuk bersubsidi itu menunjukkan lemahnya aturan hukum yang mengatur sistem distribusi sehingga acapkali sering terjadi kecurangan yang dapat merugikan banyak pihak, terutama petani. Walaupun dalam hal ini pertani sudah tergabung dalam kelompok tani, namun mereka seringkali tetap tidak bisa mendapatkan pupuk bersubsidi sesuai kebutuhan mereka hanya karena jatah pupuk mereka dijual ditempat lain, dijual di wilayah lainnya serta masih banyak penyelewengan lainnya yang dijalankan dari para pengecer sehingga pupuk tidak tepat sasaran.

Sejumlah modus penyimpangan yang sering berlangsung untuk penyaluran pupuk bersubsidi yakni penyelundupan pupuk ke luar negeri, penukaran pupuk bersubsidi menjadi nonsubsidi, penggantian isi pupuk bersubsidi yang tidak sesuai dengan label, harga pupuk bersubsidi yang melebihi HET, penjualan di luar wilayah tugas tiaptiap lini.

Pada umumnya modus penyelewengan penyaluran pupuk bersubsidi senantiasa bergerak dinamis, sama halnya yang berlangsung sekarang ini sejumlah modus penyelewengan pada distribusi pupuk bersubsidi ialah pergantian karung, melaksanakan pengurangan timbangan pupuk, mencampurkan pupuk bersubsidi terhadap zat lainnya. Penyelewengan ini bersifat dinamis sekali mengikuti aturan yang berubah namun masih ada celah untuk dicurangi dalam prakteknya.

Sistem pengawasan sangat berperan penting dalam menjaga efektifitas sistem distribusi pupuk bersubsidi agar tepat sasaran. Melalui terdapatnya pengawasan yang efektif dalam tiap lini diharapkan bisa memangkas sejumlah modus penyelewengan pupuk bersubsidi. 
Menteri Pertanian sebenarnya telah menetapkan Tim Pengawas Pupuk Bersubsidi beranggotakan atas sejumlah instansi terkait untuk melakukan pengawasan pupuk bersubsidi. Sedangkan, Gubernur untuk tingkat provinsi serta Bupati/ Walikota untuk tingkat Kabupaten/Kota membentuk KP3 sebagai koordinasi instansi terkait pada pengawasan pupuk serta pestisida. Maka sebab itu, pengawasan terhadap pupuk bersubsidi dilakukan oleh tingkat Pusat maupun Daerah.

Sebagai halnya dijelaskan pada Perpres No 15 Tahun 2011 terkait Perubahan Atas Perpres No 77 Tahun 2005 mengenai Penetapan Pupuk Bersubsidi Sebagai Barang Dalam Pengawasan bahwasanya pengawasan atas pengadaan serta distribusi pupuk bersubsidi mencakup atas jenis, jumlah, harga, tempat, waktu serta mutu. Sehingga perlunya perangkat guna mengawasai penyediaan dan penyaluran pupuk bersubsidi. Bahwasanya tiap-tiap pelanggaran atau penyimpangan atas peraturan pengadaan serta penyaluran pupuk bersubsidi seharusnya dilakukan tindak lanjut secara tegas berdasarkan aturan perundangundangan yang ada. UU Darurat No 7 Tahun 1955 mengenai Pengusutan, Penuntutan dan Peradilan Tindak Pidana Ekonomi serta ketetapan penyelenggaraan pengawasan pengadaan serta pendistribusian pupuk bersubsidi sebagai halnya tersebut, sudah dilakukan pengaturan pada
Permendag No 15/M-DAG/Per/2015 mengenai Pengadaan dan Penyaluran Pupuk Bersubsidi Untuk Sektor Pertanian, diharapkannya semua pihak bisa mengawasi berdasarkan atas wewenangnya.

Seluruh instansi yang berkaitan yang digabungkan pada Tim Pengawas Pupuk Bersubsidi Tingkat Pusat ataupun KP3 tingkat Provinsi dan Kabupaten/Kota juga melakukam pengawasan terhadap pupuk bersubsidi. Dengan optimalisasi kinerja KP3 serta PPNS di Provinsi maupun Kabupaten/Kota Pemerintah Daerah mempunyai peran aktif serta komitmen untuk melakukan pengawalan serta pengawasan untuk penyaluran serta HET pupuk bersubsidi berdasarkan wilayah wewenangnya. Serta diharapkannya tersalurnya pupuk bersubsidi yang terjamin berdasarkan atas prinsip enam (6) tepat yakni jumlah, jenis, tempat, waktu, harga serta mutu.

Demi menjaga keamanan serta terkendalinya Penyaluran Pupuk Bersubsidi, adanya kewajiban unruk memberi label yang mudah dibaca dan tidak gampang hilang maupun dihapus serta memudahkan dalam mengawsai dan menyalurkan pupuik bersubsidi yang dilakukam oleh produsen, distributor ataupun pengecer resmi yang berbunyi seperti berikut "Pupuk Bersubsidi Pemerintah, Barang dalam Pengawasan". Dengan warna pupuk yang berbeda antara Pupuk Non Subsidi dengan Pupuk Bersubsidi. Warna merah muda ("pink") 
Khusus untuk Pupuk Bersubsidi jenis Urea serta warna jngga (“oranye") untuk pupuk ZA bersubsidi diberi warna jingga ("oranye").

Pengawasan atas pengadaan maupun distribusi Pupuk Bersubsidi mencakup atas jenis, jumlah, harga, tempat, waktu serta mutu. Pemantauan maupun pengawasan penyaluran serta pemakaian Pupuk Bersubsidi maupun juga melakukan pelaporan pada Bupati/ Walikota dengan terusan pada Produsen penanggung jawab wilayah dilakukan oleh KP3 pada tingkat Kabupaten/Kota yang telah ditentukan Bupati/ Walikota, melaksanakan pemantauan serta pengawasan penyelenggaraan di wilayah kerjanya.

Laporan Pengawasan Pupuk Bersubsidi menerangkan sejumlah perihal yakni seperti di bawah ini :

a) Realisasi pendistribusian pupuk bersubsidi;

b) Keadaan stok pada Lini I hingga IV dilengkapi atas rencana kebutuhan;

c) Kondisi harga pada Lini IV;

d) Rencana Pengadaan;

e) Permasalahan serta upaya penyelesaian.

\subsection{Pertanggungjawaban dan Sanksi Pidana Pelanggar dalam Pen- distribusian Pupuk Bersubsidi}

Pertanggungjawaban pidana dalam Bahasa Inggris diketahui juga dengan sebutan yakni responsibility, ataupun criminal liability. Sesungguhnya konsep pertanggungjawaban pidana bukan cuma keterkaitan tentang hukum saja namun pula keterkaitan tentang beberapa nilai moral serta kesusilaan yang ada di masyaralat, hal ini terasa perlu guna pertanggungjawaban pidana dianggap sudah memenuhi rasa keadilan. ${ }^{4}$ Bentuk penentuan tindak pidana untuk seorang tersangka ataupun terdakwa untuk bertanggungjawab terhadap sebuah tindak pidana yang berlangsung merupakan pengertian dari pertanggungjawaban pidana. Dengan kata lain, wujud pertanggungjawaban pidana yang diperuntukkan tersangka atau terdakwa tersebut dapat dipidana atau dibebaskan.

Diteruskannya celaan yang obyektif yang terdapat dalam suatu tindakan pidana serta terpenuhinya syarat subyektif guna dipidananya dia atas suatu perbuatannya adalah arti dari pertanggungjawaban pidana menurut Roeslan Saleh. ${ }^{5}$ Maksud dari celaan objektif ialah tindakan terlarang yang dijalankan oleh seseorang, dilarangnya suatu tindakan dimaksud adalah tindakan tersebut bertentangan dan dialarang oleh hukum baik hukum meteril serta formil. Sementara itu, celaan subyektif yang dimaksud adalah menunjuk pada orang yang menjalankan tindakan dilarang

4 Hanafi, Mahrus, Sistem Pertanggung Jawaban Pidana, Cetakan pertama, Rajawali Pers, Jakarta, 2015, hlm.16

5 Roeslan saleh, Pikiran-Pikiran Tentang Pertanggung Jawaban Pidana, Cetakan Pertama, Ghalia Indonesia, Jakarta, hlm.33 
tersebut, Semisal tindakan dilaksanakan adalah merupakan tindakan yang dilarang akan tetapi di dalam diri orang itu terdapat kesalahan dan tidak mampu bertanggung jawab, pertanggungjawaban pidana itu tidak ada.

Dasar ada tidaknya tindak pidana ialah asal legalitas menuru Chairul Huda, sementara itu dapat atau tidaknya seseorang pelaku tersebut adalah dasar kesalahan, ini mempunyai arti bahwa pelaku pelanggaran akan mempunyai pertanggungjawaban pidana apabila telah melakukaan suatu perbuatan yang keliru serta bertentangan terhadap hukum. Sebenarnya, pertanggungjawaban pidana ialah satu gambaran proses yang suatu bentuk mekanisme yang diwujudkan untuk membalas terhadap ketidakpatuhan terhadap sebuah tindakan tertentu yang sudah disahkan. ${ }^{6}$

Unsur pokok pada pertanggung-jawaban pidana adalah unsur kesalahan. Dalam hal ini pertangungjwaban pidana, tindak pidana bukanlah termasuk didalamnya, namun hanya mengacu pada suatau perbuatan itu masuk dalam perbuatan hukum yang dilarang atau dilanggar, akan tetapi mengacu kepada apabila seseorang tersebut melakukan tindak pidana lalu dipidana berdasarkan perbuatan pidana tersebut apakah memiliki unsur kesalahan ataukah

${ }^{6}$ Chairul Huda, Dari Tindak Pidana Tanpa Kesalahan Menuju Kepada Tiada Pertanggung jawab Pidana Tanpa Kesalahan, Cetakan ke-2, Kencana, 2006, Jakarta, hlm.68 tindak memiliki unsur kesalahan. Dalam common law system, pertanggungjawaban pidana dalam akan terus dikaitkan dengan pemidanaan (punishment) atau mens rea,

Lebih lanjut ada keterkaitan antara pertanggungjawaban pidana dalam common law system serta mens rea, yakni bahwasanya keadaan suatu mental dalam suatu keadaan yang tidak benar atau salah ( $a$ guilty mind) adalah merupakan landasan dari pertanggungjwaban pidana. Bahwasanya guilty mind mengandung maksud sebagai kesalahan yang subjektif, yakni pikiran yang salah akan mempengaruhi orang untuk berbuat salah sehingga akan dinyatakan bersalah yang berasal pada diri pembuat, maka dari itu orang tersebut diharuskan untuk bertanggungjawab. Bahwasanya terdapat pertanggungjawaban pidana yang dijatuhkan kepada pembuat sehingga pembuat perbuatan tersebut harus dipidana. Namun apabila tidak terdapat pikiran yang keliru (no guilty mind) maka tidak adalanya pertanggungjawaban pidana yang berarti pembuat tidaklah dipidana.

Kesalahan dalam karena melanggar tata peraturan perundangan diartikan dalam kesalahan sebagai komponen dalam mens rea. Bahwasanya setiap oramg wajib bertanggungjawab terhadap perbuatan yang dilakukan melanggar undang-undang. Dalam hal ini, kesalahan dalam komponen pertanggung-jawaban menjadikan suatu control dan jaminan terhadap suatu 
kebebasan seseorang kepada orang lain.

Sehingga, jaminan tersebut akan membuat seseorang merasa dilindungi dari orang yang melaksanakan pelanggaran hukum serta kontrol bagi orang yang akan melaksanakan pelanggaran hukum, bahwasanya pelanggaran hukum yang ia lakukan harus dipertanggungjawabkan.

Perihal sistem pertanggung-jawaban pidana apa yang dianut, tidak disebutkan dengan jelas pada KUHP. Mengenai pengertian kesalahan itu sendiri tidak disebutkan dalam KUHP, hanya beberapa pasal yang menyebutkan yang dapat dijatuhi pidana adalah kesalahan berupa kesengajaan atau kealpaan, namun tidak dijelasnkan lebih lanjut dalam Undangundang mengenai pengertian kesalahan, kesengajaan maupun kealpaan itu sendiri. Tidak ada penjelasan mendetail tentang pengertian kesalahan, kesengajaan ataupun kealpaan akan tetapai hanya berdasar pada opini maupun doktrin para ahli hukum ini berarti bahwa harus dibuktikannya suatu perbuatan dengan unsur kesalahan, kesengajaan ataupun kealpaan di pengadilan, untuk memidana pelaku tindak pidana, selain itu harus dibuktikan juga unsur kesalahan disengaja atau kealpaan. ${ }^{7}$ Ini berarti bahwa pertanggungjawaban pidana erat kaitannya dengan peran hakim dalam

\footnotetext{
7 Hanafi Amrani, Mahrus Ali, 2015, Sistem Pertanggungjawaban Pidana, Jakarta, Rajawali Pers, hlm.52
}

membuktikan sejumlah unsur pertanggungjawaban pidana, dikarenakan seseorang tidak bisa dimintai pertanggung-jawaban apabila unsur-unsur tersebut tidak terbukti kebenarannya.

Pada hukum pidana kepada seseorang yang melaksanakan pelanggaran ataupun sebuah tindakan tindak pidana maka dalam pertanggungjawaban dibutuhkan sejumlah asas hukum pidana. Satu diantara asas hukum pidana ialah nullum delictum nulla poena sine pravia lege ataupun kerap dikenal melalui sebutan asas legalitas. Asas tersebut menjadi landasan utama yang tidak tertulis untuk menjatuhi pidana kepada orang yang sudah melaksanakan tindakan pidana, yang maknanya "tidak dipidana apabila tidak terdapat kesalahan”. Landasan tersebut ialah terkait dipertanggungjawabkannya seseorang mengenai tindakan yang sudah dijalankannya. Maknanya seseorang baru bisa diminta pertanggungjawabannya jika seseorang itu melaksanakan kesalahan ataupun melaksanakan tindakan yang melakukan pelanggaran terhadap aturan perundan-undangan. Asas legalitas tersebut berisi pengertian, tidak terdapat tindakan yang dilarang serta diancam dengan pidana apabila hal itu lebih dulu belum dinyatakan pada sebuah peraturan perundang-undangan. Maksud atas perihal itu ialah seseorang baru bisa diminta pertanggungjawaban jika tindakan tersebut benar-benar sudah diatur, tidak bisa 
seseorang dihukum ataupun diminta pertanggungjawaban jika aturan itu timbul sesudah terdapatnya tindakan pidana. Guna menetapkan terdapatnya tindakan pidana tidak diperbolehkan memakai kata kias dan peraturan-peraturan hukum pidana itu tidak berlangsung surut.

Putusan hakim pada perkara pidana ialah putusan yang dijatuhkan hakim sesudah melakukan pemeriksaan serta mengadili sebuah perkara pidana berdasar atas delik yang termuat pada surat dakwaan. Hakim pada perihal menjatuhkan pidana tidak boleh menjatuhkan pidana itu kecuali jika melalui sedikitnya dua alat bukti yang sah, sehingga hakim mendapatkan keyakinan jika sebuah tindak pidana memang benar berlangsung serta terdakwa itulah yang bersalah melakukan. ${ }^{8}$

Produk putusan hakim berdasarkan atas ketetapan Pasal 195 KUHAP, sah serta memiliki kekuatan hukum jika diucapkan pada sidang terbuka untuk umum. Putusan yang hakim bacakan hakim ialah wujud tanggung jawab seorang hakim pada Tuhan Yang Maha Esa, pencari keadilan, warga, Pengadilan yang lebih tinggi. Maka dari itu, putusan haruslah dibacakan pada sidang pengadilan. Acara pembacaan putusan haruslah dilaksanakan pada sidang terbuka untuk umum serta Pengadilan mempunyai kewajiban agar memberitahukan terhadap

\footnotetext{
${ }^{8}$ Lilik Mulyadi. Hukum Acara Pidana, PT Citra
} Aditya Bakti, Bandung 2007, hlm. 152-153 warga serta sejumlah pihak yang mempunyai perkara mengenai jadwal pembacaan putusan tersebut. $^{9}$

Penjatuhan pidana oleh hakim lewat putusan pengadilan, ialah penerapan tugas hakim selaku pejabat penegak hukum yang memberi putusan atas perkara yang diajukan, yang mana pada perkara pidana, tidak terlepas atas sistem pembuktian, yang menetapkan jika sebuah hak ataupun peristiwa ataupun kesalahan dipandang sudah terbukti, disamping terdapatnya sejumlah alat bukti berdasarkan UU.

Produsen pupuk, dalam hal ini PT. Mega Berlian Indonesia yang melaksanakan tindak pidana sengaja melakukan pengedaran pupuk yang tidak sesuai terhadap label, yang berkedudukan di Lampung Utara pada Putusan Pengadilan Negeri Kotabumi No 86/Pid.Sus/2015/PN.Kbu.

Label di karung pupuk KCL serta NPK yang sudah dilakukan pengedaran ataupun dijual dari PT. Mega Berlian Indonesia tidak sesuai terhadap ketetapan, yang mana PT. Mega Berlian Indonesia mencantumkan kandungan unsur hara yang belum dilaksanakan pengujian laboratorium dan mencantumkan No 800/1921/23-LU/I11.3/ 2014 Rekomendasi Dinas Pertanian dan Petemakan Kabupaten Lampung Utara yang ditujukan terhadap Badan Penanaman Modal dan Pelayanan Terpadu Satu Pintu

\footnotetext{
${ }^{9}$ Ibid. hlm.154
} 
Kabupaten Lampung Utara guna pembuatan izin usaha perusahaan selaku nomor pendaftaran dari Departemen Pertanian.

Berdasar atas sertifikat hasil pengujian laboratorium penguji dan kalibrasi balai riset serta standarisasi industri Bandar Lampung No 0851 tanggal 11 Juni 2015 yang ditandatangani Manajer Puncak Agus Kuntoro atas pupuk KCL yang dihasilkan dari PT. Mega Berlian Indonesia dengan memakai metode SNI 02-2805-2005 melalui hasil pengujian kandungan K20 2,28\%, dan berdasar atas sertifikat hasil pengujian laboratorium penguji dan kalibrasi balai riset serta standarisasi Industri Bandar Lampung No 0863 tanggal 15 Juni 2015 yang ditandatangani Manajer Teknik M. Nasyaruddin atas pupuk NPK yang dihasilkan dari PT. Mega Berlian Indonesia dengan memakai metode SNI 2803-2012 melalui hasil pengujian kandungan K20 0,04\%, Nitrogen (N) $2,34 \%$ maupun P A $0,0075 \%$ tidak sesuai terhadap batas toleransi $8 \%$.

Hal itu berlawanan terhadap Pasal 15 PP No 8 Tahun 2001 mengenai Pupuk Budidaya Tanaman yang menyampaikan jika perorangan ataupun badan hukum dilarang melakukan pengedaran pupuk anorganik yang tidak sesuai terhadap keterangan yang ada di label maupun pupuk anorganik yang telah rusak. Lain daripada itu berlawanan terhadap Pasal 8 Permentan No 43/Permentan/SR.140/8/2011 mengenai
Syarat dan Tata Cara Pendaftaran Pupuk Anorganik yang menyampaikan jika mutu serta efektivitas produk pupuk anorganik harus dilandaskan dari hasil uji mutu serta uji efektivitas dari Lembaga Pengujian yang sudah terakreditasi ataupun yang ditetapkan Menteri Pertanian.

Pelaku tindak pidana melakukan pengedaran pupuk yang tidak sesuai terhadap label semestinya dipidana maksimum sesuai atas dakwaan Pasal 60 ayat (1) UU No 12 Tahun 1992 mengenai Sistem Budidaya Tanaman yakni pidana penjara paling lama lima (5) tahun serta denda paling banyak Rp. 250.000.000.

Majelis hakim yang menangani perkara ini sudah menjatuhkan pidana kepada I Gede Berlian MS Bin I Gede Putra sebagai Direktur PT. Mega Berlian Indonesia melalui amar putusan seperti berikut :

1. Menyatakan Terdakwa I Gede Berlian MS Bin I Gede Putra sudah terbukti secara sah serta meyakinkan bersalah melaksanakan tindak pidana "dengan sengaja melakukan pengedaran pupuk yang tidak sesuai dengan label";

2. Menjatuhkan pidana kepada terdakwa I Gede Berlian MS Bin I Gede Putra maka dari itu dengan pidana penjara selama sembilan (9) bulan serta denda Rp.2.000.000 melalui ketetapan apabila denda tidak dibayar harus diganti melalui pindana penjara selama tiga (3) bulan; 
3. Menetapkan lamanya penahanan yang sudah dilaksanakan oleh terdakwa dikurangkan semuanya dari pidana yang dijatuhkan;

4. Memerintahkan terdakwa tetap ada dalam tahanan;

5. Membebankan terhadap terdakwa guna melakukan pembayaran biaya perkara sejumlah Rp.2000.

Indonesia yang mayoritasnya penduduknya adalah petani, sehingga pupuk bersubsidi memiliki arti dan peranan penting, antara lain :

1) Peranan pupuk benar-benar penting untuk peningkatan produktifitas serta produksi komoditas pertanian untuk rangka menjadikan terwujudnya Ketahanan Pangan Nasional;

2) Untuk meningkatkan kemampuan petani untuk implementasi pemupukan berimbang dibutuhkan terdapatnya subsidi pupuk.

Oleh karena pentingnya pupuk bersubsidi bagi petani dan tindak pidana yang Terdakwa ( H. Arif Nur Saifullah Bin H. Mukayat) lakukan itu sangat merugikan petani, antara lain :

- Terdakwa merupakan pemilik toko Sekar Mulyo selaku pengecer/kios resmi pupuk yang bertempat di Sukomoro, Nganjuk;

- Terdakwa telah membantu mengajukan RDKK yaitu Kelompok Tani Margo Rukun 2 dengan Ketua Masdi, Suko
Makmur dengan Ketua Sumardi, dan Sumber Pangan dengan Ketua Kalimin, lalu diserahkan pada distributor CV. Citra Nusantara, sebagai tembusan dalam rangka pemenuhan kebutuhan sesuai RDKK kepada Dinas Pertanian Kabupaten Nganjuk, ke Dinas-Dinas Provinsi serta Kementrian Pertanian ke Produsen PT. Petrokimia Gresik;

Kemudian Produsen mengirimkan pupuk tersebut ke wilayah Nganjuk, berikutnya Distributor mengambil pupuk PETROGANIK langsung dikirim ke Terdawa selaku pengecer/kios pada awal bulan September 2016 sebanyak 150 sak, persak 40kg, dengan jumlah keseluruhan yaitu 60 ton dengan harga persak Rp. 17.272,-;

- Setelah terdakwa memperoleh pupuk PETROGANIK tersebut, pupuk tersebut tidak disalurkan ke kelompok tani melainkan dipergunakan sendiri untuk tanaman tebu yang ditanam di wilayah Desa Tugu Kecamatan Purwosari Kabupaten Nganjuk, diangkut dengan Truck Mitsubishi No Pol AG-9713-GB;

- Tindakan terdakwa itu diatur serta diancam pidana menurut Pasal 30 ayat (2) Jo. Pasal 21 ayat (1) Permendag RI No 15/M-DAG/PER/4/2013 mengenai Pengadaan dan Penyaluran Pupuk Bersubsidi Untuk Sektor Pertanian Jo. Pasal 6 ayat (1) huruf b UU Drt. No 7 Tahun 1955 terkait Pengusutan 
Penuntutan dan Peradilan Tindak

Pidana Ekonomi;

Majelis hakim yang menangani persoalan ini sudah menjatuhkan pidana kepada H. Arif Nur Saifullah Bin H. Mukayat selaku pengecer/kios resmi melalui amar putusan seperti berikut :

1. Menyatakan terdakwa, telah terbukti secara sah serta meyakinkan bersalah melaksanakan tindak pidana "Memperjualbelikan Pupuk Bersubsidi Di Luar Peruntukannya dan/atau Di Luar Wilayah Tanggung Jawabnya";

2. Menjatuhkan pidana pada terdakwa tersebut maka dari itu dengan pidana penjara selama empat bulan;

3. Menetapkan barang bukti berupa :

- 1 unit Truck Mitsubishi No. Pol AG9713-GB warna kuning tahun 1997, No Ka FE119E072261, No Sin. 4D34C92268 berikut SKPD pengganti STNK;

- Pupuk bersubsidi pemerintah jenis pupuk organik PETROGANIK PT. Pupuk Indonesia (Persero) Group sebanyak 150 sak dengan berat @ 40kg, total keseluruhan 60 Ton;

4. Membebankan terhadap terdakwa untuk melakukan pembayaran biaya perkara sejumlah Rp 5.000,-

Peraturan yang mengatur tentang pendistribusian pupuk bersubsidi harus selalu diperbarui apabila terjadi tindak pidana ekonomi yang memanfaatkan celah hukum dalam aturan tersebut sehingga menguntungkan pelaku dan sangat merugikan kelompok tani dan masyarakat luas. Para penegak hukum harus secara teliti dan cermat dalam menuntaskan kasus-kasus tindak pidana ekonomi yang berkaitan dengan pendistribusian pupuk bersubsidi. Apabila yang melakukan tindak pidana tersebut adalah organ dari sebuah perusahaan yang berbadan hukum ada baiknya perusahaan tersebut dimintakan pembubaran badan usaha yang berbadan hukum dalam dakwaan maupun tuntutan, sehingga perusahaan tersebut tidak merugikan kelopok tani dan masyarakat luas lagi.

\section{KESIMPULAN}

Mekanisme Pendistribusian Pupuk telah diatur sebagaima rupa oleh Permendag No 15/MDAG/PER/14/2013 mengenai Pengadaan dan Pendistribusian Pupuk Bersubsidi untuk Sektor Pertanian, namun pada praktek di lapangan masih banyak sekali celah dalam peraturan tersebut sehingga banyak sekali kecurangan dalam proses pendistribusiannya. Para pelaku tindak pidana dalam proses pendistribusian pupuk bersubsidi dapat dilakukan secara perorangan maupun organ-organ dalam sebuah badan hukum, mengingat pengecer resmi juga bisa berbentu perseroan terbatas, namun dalam contoh kasus yang diangkat penulis dalam studi kasus lebih banyak 
pelaku perorangan yang sifat tindak pidananya terorganisir dengan baik dan saling berkesinambungan sehingga me-nimbulkan kerugian baik untuk kelompok tani maupun masyarakat luas, dan dapat dikategorikan sebagai tindak pidana ekonomi.

\section{DAFTAR PUSTAKA}

\section{BUKU}

Chairul Huda, 2006, Dari Tindak Pidana

Tanpa Kesalahan Menuju Kepada

Tiada Pertanggung jawab Pidana

Tanpa Kesalahan, Cetakan ke-2, Kencana, Jakarta, 2006.

Hanafi, Mahrus, Sistem Pertanggung Jawaban Pidana, Cetakan pertama, Rajawali Pers, Jakarta, 2015.

Lilik Mulyadi, Hukum Acara Pidana, PT Citra Aditya Bakti, Bandung, 2007.

Peter Mahmud Marzuki, Penelitian Hukum, Kencana, Jakarta, 2010.

Roeslan saleh, Pikiran-Pikiran Tentang Pertanggung Jawaban Pidana, Cetakan Pertama, Ghalia Indonesia, Jakarta

\section{Perundang-Undangan}

Undang-undang No. 1 Tahun 1946 tentang Peraturan Hukum Pidana;

Undang-undang No. 8 Tahun 1981 tentang Hukum Acara Pidana;
Undang-undang Nomor 7/Drt./ Tahun 1955 tentang Pengusutan, Penuntutan, dan Peradilan Tindak Pidana Ekonomi;

Undang-Undang Nomor 7 Tahun 2014 tentang Perdagangan

Peraturan Pemerintah No. 8 Tahun 2001 tentang Pupuk Budidaya Tanaman;

Peraturan Presiden Nomor 77 Tahun 2005 tentang Penetapan Pupuk Bersubsidi Sebagai Barang Dalam Pengawasan;

Peraturan Presiden Republik Indonesia Nomor 15 Tahun 2011 tentang Perubahan Atas Peraturan Presiden Nomor 77 Tahun 2005 Tentang Penetapan Pupuk Bersubsidi Sebagai Barang Dalam Pengawasan;

Peraturan Presiden No. 71 Tahun 2015 tentang Penetapan dan Penyimpanan Barang Kebutuhan Pokok dan Barang Penting

Peraturan Menteri Perdagangan Nomor : 15/M-DAG/PER/4/2013 tentang pengadaan dan penyaluran pupuk bersubsidi untuk sektor pertanian;

Peraturan Jaksa Agung Nomor PER028/A/JA/10/2014 tentang Pedoman Penanganan Perkara Pidana dengan Subjek Hukum Korporasi 
Peraturan Mahkamah Agung No. 13 Tahun 2016 entang Tata Cara Penanganan Tindak Pidana oleh Korporasi

Putusan Pengadilan Negeri Kotabumi Nomor : 86/Pid.Sus/2015/PN.Kbu

Putusan Pengadilan Negeri Nganjuk Nomor: 307/Pid.Sus/2016/PN.Njk.

\section{INTERNET}

www.psp.pertanian.go.id/index.php/page/p

ublikasi/300, diunduh 16/01/2019, 10.58 WIB.

https://www.jitunews.com/read/56356/para

h-begini-modus-penyelewengan-

pupuk-urea-subsidi-di-riau, diakses 15 januari 2019, 11.20 WIB

https://tirto.id/akar-masalah-kelangkaanpupuk-bersubsidi-yang-terus-terjadicARs, diunduh tanggal 1 Maret 2019, $10.00 \mathrm{WIB}$

\section{BIODATA SINGKAT PENULIS}

Danu Bagus Pratama memperoleh Gelar Sarjana Hukum pada Fakultas Hukum Universitas Brawijaya Malang tahun 2015. Pada saat ini sedang menyelesaikan program Magister Hukum pada Fakultas Hukum Universitas Airlangga Surabaya. 